\title{
Exchange Traded Fund in Indian Stock Market
}

\author{
Dr.R.Umarani \& Mrs.D.Deepa, SNR Sons College, Coimbatore - 641006.
}

Abstract: Exchange traded funds (ETFs) are one of the most innovative financial products introduced on exchanges. ETFs in India, investors need D-MAT account and many Indian investors do not have these accounts and therefore do not consider ETFS. ETFs have been limited to broad indexes when compare other countries markets. In USA 75\% ETFs are affect the total turnover of U.S stock Exchange but in India only the 25\% of ETFs are affect the total turnover of Indian Stock market. Indian stock market regulators only can regulate the way of trading ETFs and Create awareness about riskless ETFs trading to Indian traders.

\section{Introduction}

An ETF refers to a diversified basket of securities that is traded in real time like an individual stock on an exchange.Unlike regular open-ended mutual funds, ETFs can be bought and sold throughout the trading day like any other stock.An ETF is similar to an index fund, but the ETFs can invest in either all of the securities or a representative sample of the securities included in the index. Exchange-traded funds first came into existence in the USA in 1993. Importantly, the ETFs offer a one-stop exposure to a diversifi ed basket of securities that can be traded in real time like an individual stock.

\section{MEANING : EXCHANGE TRADED FUND(Etfs)}

A security that tracks an index, a commodity or a basket of assets like an index fund, but trades like a stock on an exchange. ETFs experience price changes throughout the day as they are bought and sold. Because it trades like a stock, an ETF does not have its net asset value (NAV) calculated every day like a mutual fund does. By owning an ETF, you get the diversification of an index fund as well as the ability to sell short, buy on margin and purchase as little as one share. Another advantage is that the expense ratios for most ETFs are lower than those of the average mutual fund. When buying and selling ETFs, you have to pay the same commission to your broker that you'd pay on any regular order.

\section{Etfs: EVOLUTION AND RECENT TRENDS}

The first ETF in India, the "NIFTY BEES (Nifty Benchmark Exchange Traded Scheme) based on Nifty 50 was launched inDecember 2001 by Benchmark Mutual Fund. It is bought and sold like any other stock on NSE and has all characteristicsof an index fund. As of March 2013, there were 35 ETFs listed on NSE. The ETF based on Sensex is SPICE (SensexPrudential ICICI Exchange Traded Fund) which was launched by -Prudential ICICI. Growth in Gold ETFs have seen a rising trend as shown in Following Figure however other ETFs have seen a decline in activity from 2007 to 2011.

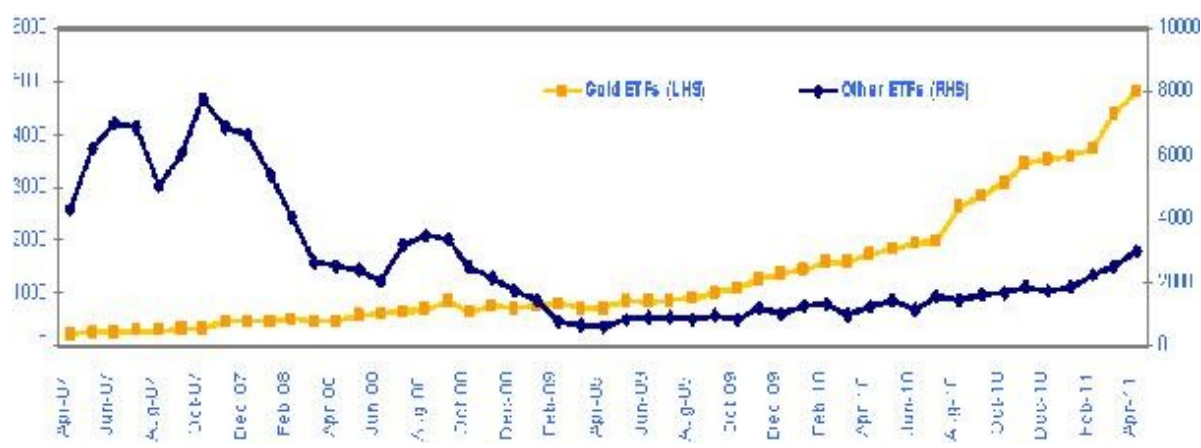

ETFs have been limited to broad indexes. The liquidity issue raises concerns about the spreads of ETFs. In contrast to developed markets, the ETF market in countries such as India is dominated by retail investors. Hence, securities regulators are even more inclined to be conservative in allowing complicated products. In order to trade ETFs in India, investors need demat/broking accounts and many Indian investors do not have these accounts and therefore do not consider ETFs. Banks play a large role in the Indian financial markets and are the biggest distributors. They find it easier to sell open-end mutual funds that do not require demat accounts. They also do not want to be seen as selling stock market products for the fear of additional regulation and scrutiny. There are 31 ETFs listed in India as of September 2013, with total assets of \$2.5 billion. 
They are listed on the NSE and/or BSE. As on september 2013, 35 Exchange Traded Funds are listed in Indian Stock Market is followed below.

\section{Name list of Exchange Traded Fund in Indian stock market}

\begin{tabular}{|c|c|c|c|}
\hline $\mathrm{NO}$ & Symbol & Underlying & Security Name \\
\hline 1 & BANKBEES & Bank Nifty & Goldman Sachs Mutual Fund - Bank Nifty ETF \\
\hline 2 & GOLDBEES & Gold & Goldman Sachs Mutual Fund - Gold ETF \\
\hline 3 & GOLDSHARE & Gold & UTI Mutual Fund - Gold ETF \\
\hline 4 & JUNIORBEES & Junior Nifty & Goldman Sachs Mutual Fund - Nifty Junior ETF \\
\hline 5 & KOTAKGOLD & Gold & Kotak Mutual Fund - Gold ETF \\
\hline 6 & KOTAKPSUBK & $\begin{array}{lll}\text { CNX } & \text { PSU } & \text { Bank } \\
\text { Index } & & \\
\end{array}$ & Kotak Mutual Fund - PSU Bank Index ETF \\
\hline 7 & LIQUIDBEES & $\begin{array}{l}\text { Government } \\
\text { Securities }\end{array}$ & Goldman Sachs Mutual Fund - Liquidbees ETF \\
\hline 8 & NIFTYBEES & Nifty & Goldman Sachs Mutual Fund - Nifty ETF \\
\hline 9 & PSUBNKBEES & $\begin{array}{lll}\text { CNX } & \text { PSU Bank } \\
\text { Index } & & \\
\end{array}$ & Goldman Sachs Mutual Fund - PSU Bank ETF \\
\hline 10 & QGOLDHALF & Gold & Quantum Mutual Fund - Gold ETF \\
\hline 11 & QNIFTY & Nifty & Quantum Mutual Fund - Nifty ETF \\
\hline 12 & RELBANK & Bank Nifty & Reliance Mutual Fund - Bank Nifty ETF \\
\hline 13 & RELGOLD & Gold & Reliance Mutual Fund - Gold ETF \\
\hline 14 & SBIGETS & Gold & SBI Mutual Fund - Gold ETF \\
\hline 15 & SHARIABEES & Shariah Index & Goldman Sachs Mutual Fund - Shariah Index ETF \\
\hline 16 & KOTAKNIFTY & Nifty & Kotak Mutual Fund - Nifty ETF \\
\hline 17 & HNGSNGBEES & Hang seng Index & Goldman Sachs Mutual Fund - Hang Seng ETF \\
\hline 18 & RELIGAREGO & Gold & Religare Mutual Fund - Gold ETF \\
\hline 19 & M50 & Nifty & Motilal Oswal Mutual Fund - Nifty ETF \\
\hline 20 & HDFCMFGETF & Gold & HDFC Mutual Fund - HDFC Gold Exchange Traded Fund \\
\hline 21 & IPGETF & Gold & $\begin{array}{l}\text { ICICI Prudential Mutual Fund-ICICI Prudential Gold Exchange Traded } \\
\text { Fund }\end{array}$ \\
\hline 22 & INFRABEES & CNX Infra Index & Goldman Sachs Mutual Fund - Infra Goldman Sachs ETS \\
\hline 23 & AXISGOLD & Gold & Axis Mutual Fund - Axis Gold ETF \\
\hline 24 & M100 & Midcap & Motilal Oswal Mutual Fund - Midcap ETF \\
\hline 25 & N100 & Nasdaq100 & Motilal Oswal Mutual Fund - Nasdaq ETF \\
\hline 26 & BSLNIFTY & Nifty & Birla Sun Life Nifty ETF - Growth \\
\hline 27 & IIFLNIFTY & Nifty & IIFL Mutual Fund - Nifty ETF \\
\hline 28 & BSLGOLDETF & Gold & BIRLA SL GOLD ETF \\
\hline 29 & RELGRNIFTY & Nifty & RELIGARE MF - NIFTY ETF \\
\hline 30 & IDBIGOLD & Gold & IDBI Mutual Fund - IDBI Gold ETF \\
\hline 31 & CRMFGETF & Gold & $\begin{array}{l}\text { Canara Robeco Mutual Fund - Canara Robeco Gold Exchange Traded } \\
\text { Fund }\end{array}$ \\
\hline 32 & MGOLD & Gold & Motilal Oswal Mutual Fund - Motilal Oswal MOSt Shares Gold ETF \\
\hline 33 & NIFETF & Nifty & $\begin{array}{l}\text { ICICI Prudential Mutual Fund - ICICI Prudential Nifty ETF - } \\
\text { GROWTH }\end{array}$ \\
\hline 34 & RELCNX100 & CNX100 & R Shares CNX 100 Fund \\
\hline 35 & ICCNX100 & CNX100 & ICICI Prudential CNX 100 ETF - Growth \\
\hline
\end{tabular}

Source: ETF Data Base ICRA As on September 2013

\section{TRADING STATISTICS OF EXCHANGE TRADED FUNDS(Etfs) IN INDIA}

Several emerging markets now trade ETFs; in addition, emerging market ETFs are also listed in foreign markets. Broad based emerging market ETFs were introduced almost ten years ago. ETF activity is Asia is quite limited relative to other regions. Japan, Hong Kong, Korea and Taiwan have the most ETF activity in Asia. Among the BRIC countries of Brazil, China, India and Russia, ETF activity is highest in China and Brazil, followed by India and barely exists in Russia. ETF activity is concentrated only in a few countries around the world. 
As of May 2011, there were 47 ETFs that offer Russian exposure, 69 ETFs offer exposure to Brazil, 160 offer exposure to China, and there are 43 India-related ETFs listed in the U.S. In May 2011, Direxion Funds filed with the SEC to introduce nine new India-related ETFs that are not leveraged.15 Emerging Global Advisors has also filed for additional Indian ETFs with nine of them focusing on different sectors of the economy. These ETFs provide investors another option to obtain easy exposure to foreign markets.

ETFs trading in emerging markets are typically of the vanilla type with synthetic or leveraged ETFs not being allowed in most emerging markets. One of the issues in emerging markets is that only stocks in broad based indexes tend to be liquid; therefore, ETFs have been limited to broad indexes. The liquidity issue raises concerns about the spreads of ETFs. In contrast to developed markets, the ETF market in countries such as India is dominated by retail investors. Hence, securities regulators are even more inclined to be conservative in allowing complicated products. In order to trade ETFs in India, investors need demat/broking accounts and many Indian investors do not have these accounts and therefore do not consider ETFs. Banks play a large role in the Indian financial markets and are the biggest distributors. They find it easier to sell open-end mutual funds that do not require demat accounts. They also do not want to be seen as selling stock market products for the fear of additional regulation and scrutiny. Past four years India's Trading statistics of Exchange Traded Fund as followed below.

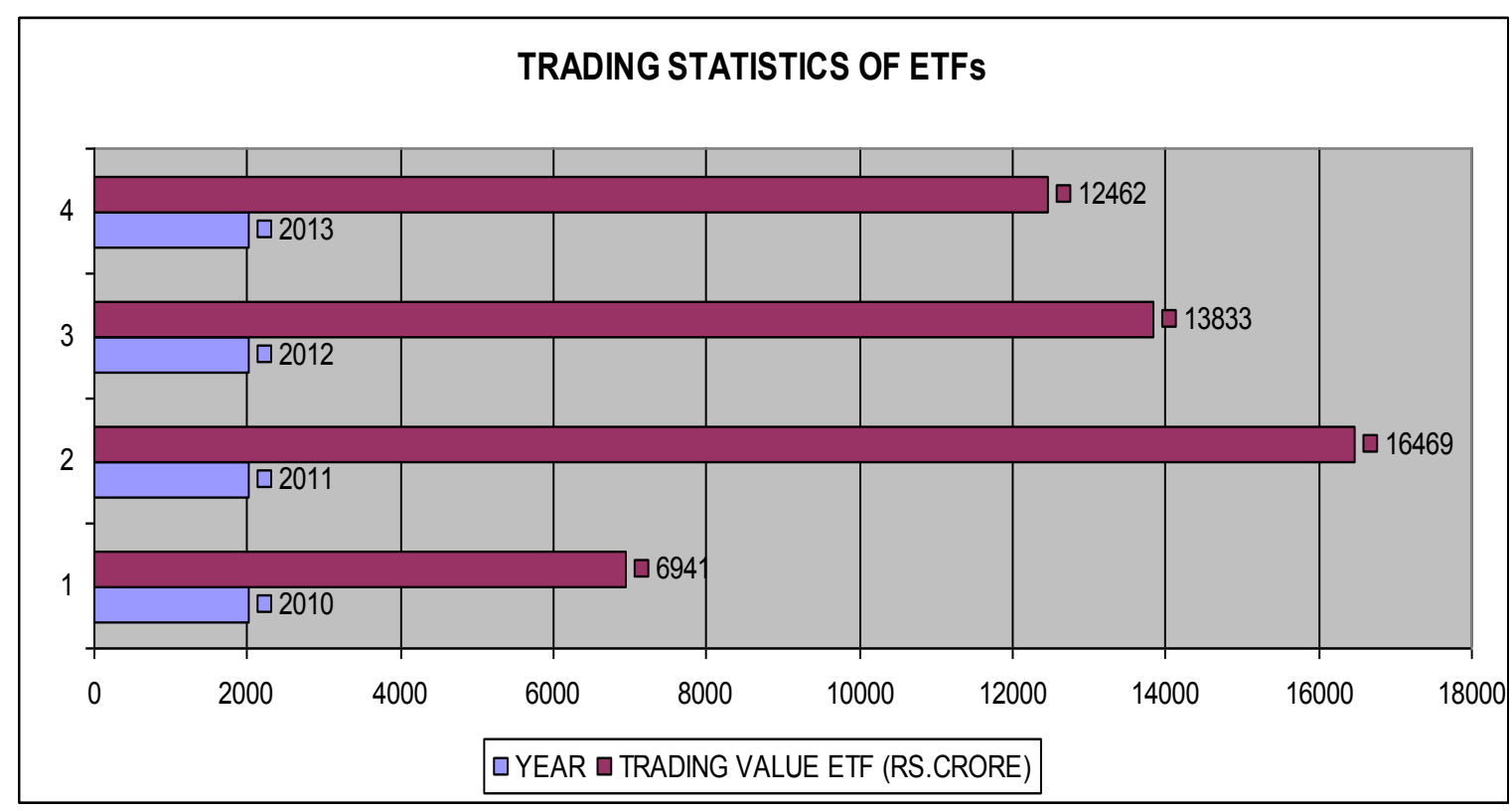

SOURCE: ICRA, CSO

\section{TRADING STATISTICS OF INDIAN STOCK MARKET}

Both National stock Exchange and Bombay stock Exchange markets will affect the indian economy. ndian economy is the third largest economy in the world in terms of purchasing power. It is going to touch new heights in coming years. As predicted by Goldman Sachs, the Global Investment Bank, by 2035 India would be the third largest economy of the world just after US and China. It will grow to $60 \%$ of size of the US economy. This booming economy of today has to pass through many phases before it can achieve the current milestone of $9 \%$ GDP. Both NSE and BSE stock market trading statistics as follows.

\section{I . Trading Statistics of Bombay Stock Exchange}

\begin{tabular}{|l|l|}
\hline YEAR & $\begin{array}{l}\text { TRADING VALUE OF } \\
\text { BSE(BILLION) }\end{array}$ \\
\hline $2009-10$ & 13788.09 \\
\hline $2010-11$ & 11050.27 \\
\hline $2011-12$ & 6674.98 \\
\hline $2012-13$ & 5487.74 \\
\hline $2013-14$ & NIL \\
\hline
\end{tabular}




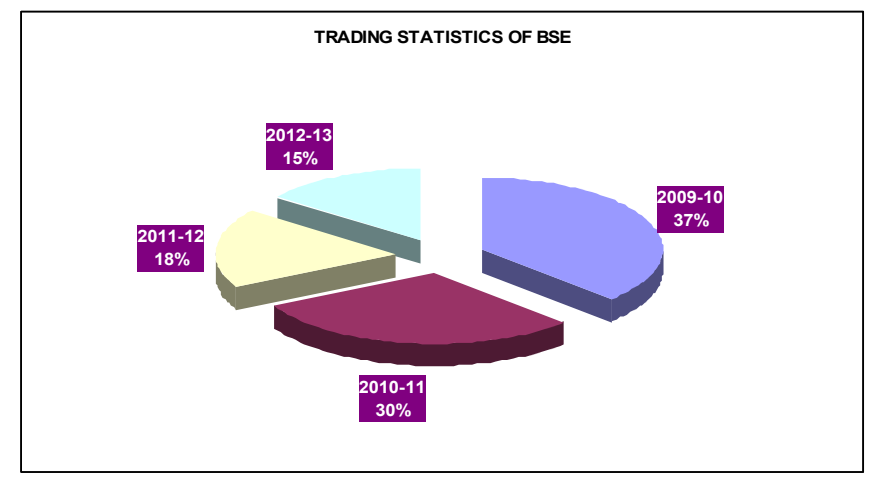

Note : Turnover pertains to the spot market at BSE.

Source : Bombay Stock Exchange Limited (BSE).

\section{I . Trading Statistics of National Stock Exchange}

\begin{tabular}{|l|l|}
\hline YEAR & $\begin{array}{l}\text { TRADING VALUE OF } \\
\text { NSE(BILLION) }\end{array}$ \\
\hline $2009-10$ & 41380.24 \\
\hline $2010-11$ & 35774.1 \\
\hline $2011-12$ & 28108.93 \\
\hline $2012-13$ & 27082.79 \\
\hline $2013-14$ & 11572.83 \\
\hline
\end{tabular}

TRADING STATISTICS OF NSE

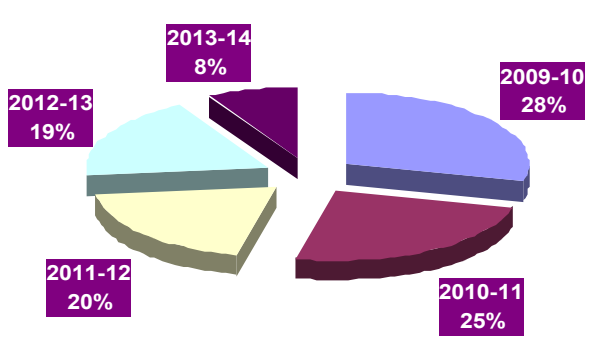

Note : Turnover pertains to the spot market at NSE.

Source : National Stock Exchange of India Ltd. (NSE).

\section{Conclusion}

ETFs have grown tremendously during the last decade and have become a significant part of the equity market activity; hence, regulators are keeping a close watch on any potential impact of these products on financial stability and market volatility. In India, trading in ETFs has been quite limited relative to the U.S. and Europe. Only the $25 \%$ of ETFs are affect the total turnover of Natinal Stock Exchange and Bombay Stock Exchange. Emerging market regulators have been appropriately cautious in not allowing complex ETFs. In countries such as India, trading in ETFs has been quite limited relative to the U.S. and Europe ETFs based on broad market indexes with sufficient liquidity appear to be suitable products for retail customers.

Local regulators in emerging markets have typically allowed only simple ETFs in the local market. However, foreign providers can create and list complex ETFs in the foreign market. ETFs are one of the most successful products introduced on exchanges in recent years. Regulators will need to tread carefully to manage risks and yet not impose unnecessary regulation. There is little by way of data and facts concerning the risks of ETFs. Indian stock market regulators only play important role in encourage to trade ETFs in stock market and to create awareness about riskless, profitable ETFs to stock traders. And also Academic scholars can play a role by conducting comprehensive and unbiased analysis 


\section{References:}

[1]. Madhavi Lokahande, Shruti manisha, “ETF: In Indian Market”, The management accountant, volume no 46, no 9, september 2011, page no $770-774$

[2]. Bhaskar Mutyala,Padmaja.P, "ETFs in India yet to achieve a growth trajectory", Portfolio Organizer ICFAI University Press, January2010 page no 26-30

[3]. Reena Agarwal,"Growth of global ETFs and regualtory challenges", NSE Working Paper January 2012 page no 19-21

[4]. Handbook of statistics of Indian Economy published by Reserve Bank of India 2012-2013 page no 316-317

[5]. retrieved from // www.tradingecnomics.com

[6]. retrieved from // www.etfdb.com 